\title{
REVITALISASI ISLAM KULTURAL
}

\author{
M. Mukhsin Jamil \\ IAIN Walisongo Semarang \\ e-mail: muhsienjamiel@yahoo.com
}

\begin{abstract}
This research aim to explore one of Islamic movements in Indonesia after reformation of 1998. By using qualitative method, it is clear that the demarcation betweeen Islamic tradisionalism and Islamic modernism fluided culturally. Although at the same time polarization both become more political, which is made Indonesian Islamic mainstream loosed elan vital as sosial and cultural movement. There is the contradictory trends in the dynamic of Islamic thought and movement introduced by Islamc minority groups. In one side the trends are multiculturalism, anti coruption movement and appreciation to the local cultures which is ignorenced before by Islamic movement in Indonesia. In other side, political oriented in many Islamic movement is stronger. The dominant of traditional constructions of Islamic polical thought of sunni (fiqh al-siyasah) influenced to the Islamic movement to state orientation at same time ignored the society with their problem and cultural expression. The cultural Islam proposed new understanding to Islamic traditions with hermeneutic and remove the locus of movement forum political Islam to civil Islam.
\end{abstract}

\begin{abstract}
$* * *$
Penelitian ini bertujuan untuk menjelajahi salah satu gerakan Islam di Indonesia setelah reformasi 1998. Dengan menggunakan metode kualitatif, akan menjadi jelas demarkasi antara Islam tradisional dan Islam modernis secara kultural. Meski polarisasi kedua kelompok keagamaan itu kerap bernuansa lebih politis, sehingga menghilangkan elan vital Islam Indonesia sebagai gerakan sosial dan budaya. Tetapi ada tren kontradiktif dalam dinamika pemikiran dan gerakan Islam yang dilakukan oleh kelompok minoritas Islam. Di satu sisi trennya adalah multikulturalisme, gerakan anti korupsi, dan apresiasi terhadap budaya lokal yang telah dikembangkan oleh gerakan Islam sebelumnya. Di sisi lain, orientasi politik kelompok keagamaan juga semakin meningkat. Dominasi pemikiran politik tradisional Sunni turut mempengaruhi pola gerakan Islam kepada negara dan pada saat yang sama mengabaikan masyarakat dengan problem kebudayaan mereka. Islam kultural mencoba untuk meniupkan pemahaman baru dalam tradisi Islam dengan hermeneutika dan menggeser arah gerakan Islam politik kepada Islam sipil.
\end{abstract}

Keywords: Islam kultural, civil Islam, Islam politik 


\section{A. Pendahuluan}

Reformasi Indonesia Mei 1998 telah membuat perubahan yang luas atas dasar-dasar dan konstelasi politik Indonesia mutakhir. Pertama, runtuhnya hegemoni Orde Baru dengan pilar utama Golkar yang ditopang oleh birokrasi dan militer. Kedua, munculnya sistem politik multi partai yang memberi peluang bagi setiap kelompok politik dengan beraneka latar belakang aspirasi dan ideologi yang meramaikan panggung politik nasional. Ketiga, terjadinya pergeseran hubungan antara Islam dan negara antara lain ditandai dengan: (1) intensifnya gerakan Islam formal melalui wadah partai politik, dan (2) terserapnya pemimpin dan aktivis Islam yang mewakili gerakan Islam substansial ke dalam kehidupan negara.

Dinamika sosial politik pasca reformasi juga telah memunculkan tantangan-tantangan kultural dan politik baru yang merubah seluruh orientasi dan tampilan gerakan Islam Indonesia. Ada regrouping gerakan Islam Indonesia dan gerakan lainnya pasca reformasi ke dalam ideologi dan format gerakan masa lalu; Islam tradisionalis, Islam modernis, nasionalis. Telah terjadi pergeseran dan persilangan, yang mengakibatkan banyak cabang dan sayap dalam gerakan-Islam Indonesia kontemporer yang ditandai dengan munculnya organisasi dan gerakan Islam baru. NU yang tradisional sayapnya membentang dari ujung pemikiran yang konservatif hingga liberal. Langkah dan gerakannya juga tampak terekspresi ke dalam gerakan politik maupun kultural; mengurusi persoalan sosial keagamaan dengan memantapkan dirinya sebagai jam'iyyah diniyyah ijtimā'y namun mendirikan partai politik.

Demikian pula Muhammadiyah. Organisasi ini kini bukan semata representasi satu sayap Muslim Indonesia: Islam modernis. Orang dalam Muhammadiyah, Abdul Munir Mulkhan menunjukan adanya empat varian dalam sosiologi Muhammadiyah: Muhammadiyah Puritan, Muhammadiyah Toleran, Muhmmadiyah NU dan Muhammadiyah Abangan. Sayap politik organisasi ini juga membentang dari mulai fundamentalis radikal hingga moderat dan akomodatif. Di seberang organisasi Muslim terbesar Muhammadiyah dan NU tumbuhlah organisasi dan kelompok-kelompok Islam baru, Front Pembela Islam (FPI), Laskar Jihad, Hizbut Tahrir dan Majlis Mujahidin Indonesia (MMI). Memang Belum menjadi arus utama dalam percaturan Islam di Indonesia. Namun responsinya terhadap berbagai persoalan sosial, 
politik dan keagamaan yang sangat cepat, emosional bahkan radikal, menjadikan seruan-seruannya nyaring terdengar.

Organisasi-organisasi baru ini bukan saja menarik banyak minat kalangan muda dan terdidik Muslim perkotaan, namun telah berhasil menarik islamisme ke dalam pusat pertarungan diskursus dan gerakan. Secara kultural, gerakan ini telah membentuk trend the new urban moslem movement. Ia menjadi oase di tengah pencarian Muslim kota dalam perjalanannya melampaui kehidupan modern yang keras dan gersang. Ia menjadi penunjuk jalan praktis di tengah transisi yang ditandai dengan ketidakpastian-ketidakpastian.

Pasca reformasi telah terjadi percobaan mutakhir Islam politik di Indonesia. Sebuah percobaan mengenai bagaimana model Islam yang memungkinkan dalam kehidupan kebangsaan dan kenegaraan. Dalam kaitannya dengan pergulatan kekuatan Islam dan negara ini muncul apa yang saya namakan sebagai "total politik" dalam strategi pergerakan umat. ${ }^{1}$ Percobaan strategi ini bisa dilihat dari dinamika dua organisasi sosial keagamaan terbesar NU dan Muhammadiyah pada tahun-tahun belakangan baik pada masa pendirian partai-patai politik maupun pemilihan pimpinan politik baik pada level lokal, regional maupun nasional. Kedua organisasi ini terlibat dalam proses-proses politik praktis.

Kekalahan partai berbasis NU (PKB) dan partai berbasis Muhammadiyah (PAN) dalam pemilu legislatif, serta kegagalan kedua organisasi Islam terbesar di Indonesia itu dalam pilpres, harusnya merupakan pembelajaran politik yang teramat penting. Patronase kiai atau elite agama sebagai otoritas politik kaum nahdliyyin dalam referensi politik selama ini sudah tidak relevan lagi. Mayoritas warga NU, seperti halnya Muhammadiyah, sudah lebih rasional dalam menentukan pilihan politiknya. Intervensi dari elite NU maupun Muhammadiyah dalam mengarahkan pilihan politik umat menjadi tidak signifikan lagi.

Oleh karena itu upaya penegasan kembali (reafirmasi) dua kekuatan civil Islam itu adalah langkah strategis. Selain menghindari sugesti politik praktis

1 Pembahasan mengenai kekuatan Islam pada masa Orde Baru lihat Aminuddin, Kekuatan Islam dan Pergulatan Kekuasaan di Indonesia Sebelum dan Sesudah Runtuhnya Rezim Soeharto: (Pustaka Pelajar, Yogyakarta, 1999). 
sesaat, ini merupakan sebuah proposal yang amat penting diperjuangkan bagi pengembangan, pencerahan, sekaligus pencerdasan sumber daya umat secara optimal. Hal ini karena dimensi politis mengarah pada konsep who gets what, siapa mendapat apa. Kecenderungan semacam ini relatif menguras daya potensi umat yang dinamis dan produktif jika terus dilakukan secara terus menerus. Pada gilirannya, dimensi-dimensi kultural, seperti pendidikan, transformasi nilai-nilai substansial, penyadaran kolektif, rasionalisasi tindakan, kontekstualisasi ajaran Islam, dan berakhir pada pencerdasan bangsa secara holistik dan liberatif-transformatif, akan terabaikan.

Ini mereduksi beberapa etos pergerakan masyarakat madani (civil society), terutama NU dan Muhammadiyah, yakni: (1) etos idea of progress yang oleh Cak Nur dinyatakan sebagai daya pendorong kemajuan umat (bangsa); (2) etos keberagamaan yang egaliter, inklusif, pluralis, dan tidak menunjukkan "ekslusivisme komunal"; (3) etos nilai-nilai ketuhanan ( $r a b$ baniyah, ribbiyah) dalam tubuh umat; serta (4) etos peradaban yang menjunjung tinggi nilai-nilai keadaban (civility, madaniy) dan kedemokratisan.

Gejala keengganan para elite keagamaan untuk mengurusi wilayah kultural itu akan berpengaruh besar terhadap perkembangan internal umat Islam. Sudah saatnya, para elite santri berbesar hati untuk mengambil 'ibrah (pelajaran) dari pergumulannya dengan domain politik praktis, serta mau belajar dari konsistensi lembaga masyarakat madani, yang konsisten dalam memperjuangkan Islam kultural secara eksplisit.

Seperti pernah diungkapkan Cak Nur, Islam semakin diharapkan tampil dengan tawaran-tawaran kultural yang produktif, konstruktif serta mampu menyatakan diri sebagai pembawa kebaikan untuk semua umat manusia, tanpa ekslusivisme komunal. Inilah sebuah penegasan betapa pentingnya eksistensi Islam kultural. Dengan demikian, kecenderungan para elite santri atau kiai sebagai cultural broker, pialang budaya (Clifford Geertz), akan limbung dan cenderung merugikan dinamika umat, apabila tetap bersikukuh terjebak dalam kubangan yang sama secara partisan: politik praktis.

Proyek revitalisasi Islam kultural merupakan sebuah investasi masa depan yang besar. Betapa tidak, tampilnya wajah Islam kultural ditafsirkan secara luas bahwa Islam merupakan sumber etik-moral dan landasan kultural bagi kehidupan berbangsa dan bernegara. Tentu, ini tidak bisa diperoleh secara instan, sebab perjuangan Islam kultural merupakan inves- 
tasi yang besar dalam jangka panjang di masa mendatang. Justru, di sinilah letak dimensi politis Islam kultural, yakni tidak berujud who gets what, akan tetapi berkenaan dengan allocative politics. Yakni, politik alokatif, seperti diperkenalkan David Easton, sebagai kata kunci utama pengalokasian nilainilai tertentu dalam suatu masyarakat untuk kepentingan keseluruhan masyarakat. Maka, politik alokatif diartikulasikan dengan cara mensubstansialisasikan nilai-nilai dan etika keislaman secara inklusif di tengah pluralitas kehidupan berbangsa dan bernegara.

Menurut Syafi'i Anwar dimensi politis dari Islam kultural bersifat inklusif dan penetratif di tengah wacana pergumulan politik-kekuasaan pada level negara. Atau menurut Amien Rais (1999) diartikulasikan sebagai high politics, yaitu pengertian politik dalam arti yang luas yang melibatkan seluruh komponen masyarakat sebagai variabel politik kebangsaan.

Revitalisasi Islam kultural tampaknya merupakan salah satu agenda penting bagi Islam Indonesia ke depan. Proyek revitalisasi Islam kultural itu bukan hanya sebagai upaya untuk mengimbangi Islam politik. Di atas segalanya revitalisasi Islam kultural merupakan proses pemihakan sekaligus pemberdayaan Islam rakyat dalam rangka penciptakan negara demokratis dan pemberdayaan civil society. Paper ini bertujuan untuk merekonstruksi Islam kultural di Indonesia dan melihat dinamika dan tantangan yang dihadapi serta revitalisasi yang dimungkinkan. Secara rinci tujuan penelitian ini adalah: (1) Untuk mengetahui geneologi Islam kultural di Indonesia (2) Untuk mengetahui peta dan dinamika Islam kultural di Indonesia kontemporer (3) Untuk mengetahui tantangan yang dihadapi oleh gerakan Islam kultural (4) Untuk merumuskan pilihan strategi bagi revitalisasi Islam kultural di Indonesia

\section{B. Agama dan Negara}

Mengenai hubungan agama dan negara dalam kehidupan kebangsaan kontemporer sudah barang tentu harus diletakkan dalam konteks kebutuhan untuk mewujudkan kehidupan negara yang lebih maju dan beradab. Kemajuan dan keberadaban itu antara lain ditandai dengan keseimbangan antara negara (state) dan masyarakat beradab (civil society). Secara konseptual dinamika keseimbangan negara dan civil society akan ditentukan oleh model-model negara itu sendiri. 
Berkaitan dengan ini setidaknya ada tiga model teoritik kenegaraan. Pertama, teori instrumental yaitu teori yang memandang negara sebagai alat. Menurut pandangan teori ini, negara adalah alat kekuatan yang menguasai negara. Pandangan ini dianut oleh kalangan pluralis dan Marxis klasik. Kaum pluralis berpendapat bahwa kebijakan negara hanya merupakan hasil interaksi kekuatan-kekuatan di dalam masyarakat. Sedangkan kaum Marxis klasik memandang negara sekedar alat bagi kelas yang dominan. Louis Althuser misalkan, cenderung memandang negara sebagai perangkat penindasan. Dengan demikian negara yang dibangun atas dasar kekuasaan yang ada padanya merupakan wujud dominasi politik atas masyarakat dan negara selalu di atas masyarakat. Sebagai suatu kesatuan perangkat (alat), negara tidak hanya mempunyai fungsi spesifik. Negara mampu pula menciptakan fungsi umum sebagai perluasan-perluasan dan fungsi esensial (yang kemudian menjadikan ia sebagai mekanisme represif) yakni sebagai alat perjuangan kelas. Dalam fungsi itu negara berdiri sebagai kekuatan intervensif dalam perjuangan kelas. ${ }^{2}$

Sebagaimana yang dipahami oleh kalangan Marxis ortodok, sebagai perangkat dominasi kelas, maka ada dua dimensi hakiki negara yakni: represif dan ideologis. Kedua dimensi ini erat dengan eksistensi negara sebagai alat intervensi perjuangan kelas. Yang satu (dimensi represif) masuk dengan mamaksa sedang yang lain (dimensi ideologis) masuk dengan mempengaruhi. Berangkat dari analisis inilah muncul pembedaan antara perangkat negara represif (Represive State Aparatus/RSA) dan perangkat negara yang ideologis (Ideological State Aparatus/ISA). Untuk memperjelas pengertian dan pembedaan itu saya sengaja mengutip lebih banyak teori Althuser tentang RSA dan ISA. Sifat RSA demikian menurut Althuser, pertama-tama adalah menindas. Penindasan yang dilakukan ini selajutnya diberi arti ideologis (seolah-olah dan bernilai sah). RSA ini langsung di bawah kendali kelas penguasa yang ada dalam satu komando yang terlembagakan dalam tugas-tugas yang resmi. Berdasarkan ciri-ciri tersebut, RSA bersifat sentralistis dan sistematis. RSA ini bagi Althuser identik dengan struktur negara yang semata-mata berdiri sebagai penyangga kekuasaan yang sah dan

${ }^{2}$ Louis Althusser, Lenin, His Philosophies and The Order Essay, (London: New Left Book, 1971). 
ekplisit. Keabsahan ini memungkinkan RSA menjangkau publik lebih luas dan gerak hidupnya sendiri bersifat politik. Contoh dari RSA ini adalah birokrasi, lembaga pengadilan dan militer.

Sedangkan mengenai ISA menurut Althuser memiliki prinsip-prinsip sebagai berikut: gerak hidup ISA selalu ideologis. Yang ideologis itu demikian menurut Althuser kelak akan represif, karena memang dimaksudkan demikian (memanipulasi kesadaran). Berbeda dengan RSA, ISA tidak hanya ada dalam lingkup kekuasaan, tetapi bisa dimiliki sebagai sarana menuju kekuasaan kelompok di luar kekuasaan. Wujud ISA antara lain seperti institusi agama, institusi pendidikan dan sebagainya.

Kedua, teori struktural tentang negara. Dalam perspektif struktural ini negara dipandang memiliki kemandirian tetapi sifat relatif sebab kemandirian negara itu keluar dari konfigurasi dari kekuatan-kekuatan yang ada. Dengan demikian dalam pandangan teori ini dimungkinkan terjadi dan berlangsungnya perubahan struktur dan bukan negara sendiri yang menentukan perubahan-perubahan itu. Salah satu teori terkenal yang masuk dalam perspektif struktural ini adalah teori Negara Otoriter Birokratik (NOB) yang dikemukakan oleh Guilermo O’Donnel. Praktek otoriterianisme birokratik tidak adalah saatu praktek politik kenegaraan dalam kaitannya dengan proses pembangunan kapitalis setelah terjadi proses industrialisasi yang mendalam.

Dalam konteks kebutuhan untuk mengamankan industrialisasi yang kapitalistik, negara diharuskan untuk memobilisasi civil society dengan mempertaruhkan partisipasi masa. Dengan melakukan hal ini negara menjadi semakin tergantung pada birokrasi (baik militer maupun sipil), kaum teknokrat dan modal asing yang sangat diperlukan untuk memelihara akumulasi modal domestik, pertumbuhan ekonomi dan ekspansi pasar. Akibatnya peran militer dan teknokrat menjadi sangat dominan pada negara otoriter birokratik ini.

Beberapa ciri negara otoriter birokratik adalah (1) bersifat otoriter, (2) sangat mengandalkan birokrasi sebagai alat mencapai tujuan, (3) membendung partisipasi masyarakat, (4) melaksanakan pembangunan ekonomi dan politik secara top-down (dari atas ke bawah) dan (5) menggunakan 
ideologi teknokratis birokratis. Sementara itu O'Donnel memberikan tekanan ciri NOB yaitu adanya pluralisme terbatas. Dalam NOB demikian menurut O'Donnel ditandai dengan adanya upaya mencapai suatu pluralisme terbatas dengan menggunakan cara-cara yang represif, kooptasi dan tipikal dalam suatu jaringan kerja organisasi korporatis.

Pada aras parksis negara otoriter birokratis memiliki dua varian yaitu NOB pembangunan dan NOB rente. NOB pembangunan relatif bersih (tidak korup) dan efisien, tipe pembangunannya kapitalis dengan dukungan kaum borjuasi sehingga berhasil melaksanakan pembangunan. Model ini berhasil melahirkan New Industrial Countries (NIC's). Sedangkan NOB tipe kedua justru sebaliknya, kaum borjuasi tidak terbentuk dalam negara karena mereka mendapatkan fasilitas melalui hubungan personal dengan penguasa. Jelasnya dalam NOB rente maka para elit negara meminta imbalan rente, atau ongkos sewa dari kebijakan yang dibuat oleh negara. Para elit bertindak sebagai "rentenir" karena menyewakan jabatannya untuk kepentingan pengusaha. Jabatan birokrasi bagi elit negara menjadi semacam "alat produksi" untuk melakukan akumulasi modal melalui sistem rente. Sebagai konsekuensinya dalam NOB rente yang muncul bukan kaum borjuasi yang kuat, tetapi kelompok pengusaha yang tergantung kepada fasilitas dan perlindungan negara.

Model lain dari teori struktural adalah model Bureaucratic Polity. Sistem politik dalam negara model Bureaucratic Polity ditandai dengan kekuasaan membuat keputusan terletak sepenuhnya di tangan para penguasa negara, terutama para periwira militer dan pejabat tinggi birokrasi. Tidak ada partisipasi masyarakat, yang ada hanya mobilisasi. Di dalam politik birokrasi terjadi persaingan antara lingkaran-lingkaran birokrat dan elit militer. Elit ini, terutama presiden, akan menentukan perubahan sosial, ekonomi dengan melahirkan beberapa kemungkinan seperti: (a) pengembangan sistem politik demokratis yang kompetitif berdasarkan partai politik massa dan partisipasi warga negara; (b) gerak menuju sebuah partai tunggal, kepada suatu rezim mobilisasi dengan pendasaran ideologis; atau (c) kelangsungan politik biroktratis. ${ }^{3}$ Dalam model negara semacam ini perubahan terjadi lebih banyak karena tekanan dari luar, bukan karena lingkungan domestik.

3 Karl. D Jackson, Tradisional Authority, Islam and Rebellion A Study Of Political Behevior, (New York: Penguin, 1979), h. 21. 
Menurut Lance Castles ada tiga ciri masyarakat politik birokratik: (1) Lembaga politik yang dominan adalah aparat birokrasi; (2) Lembagalembaga politik lainnya seperti parlemen, partai politik dan kelompokkelompok kepentingan lainnya lemah dan tidak mampu melakukan kontrol terhadap birokrasi dan (3) massa di luar birokrasi secara politis dan ekonomis, pasif.

Adapun ketiga adalah teori negara sebagai kekuatan mandiri. Dalam pandangan teori ini negara merupakan subjek yang mempunyai kepentingan sendiri yang berbeda dengan kepentingan-kepentingan masyarakat yang ada. Teori Alfred Stepan tentang "Negara Statis" merupakan teori yang paling terkenal sebagai teori negara sebagai kekuatan mandiri.

Model negara organis statis berada di tengah-tengah negara pluralis liberal dan negara Marxis klasik. Negara organis berangkat dari prinsipprinsip dasar dan strategi praksisnya dalam proses-proses politik. Organis berarti totalitas suatu sistem lebih diutamakan daripada komponenkomponen yang merupakan bagiannya. Sedangkan statis berasal dari kata state yang berarti "negara yang aktif dan kuat". Dengan demikian, dalam negara organis peranan negara sangat kuat, negara memiliki kemauan dan kepentingan sendiri dan melakukan intervensi ke dalam kehidupan masyarakat.

Ada beberapa prinsip dasar negara organis diantaranya: (1) Tradisi organis statis melihat, pada prinsipnya negara mempunyai tujuan utama, yaitu moral, (2) Tujuan moral itu merupakan common good yang diarahkan kepada political community, (3) Common good merupakan prinsip yang berlaku dalam mengontrol setiap kepentingan, (4) Negara dalam tradisi organis statis memiliki sifat yang kuat dan intervensionis; tegasnya, negara mempunyai peran yang relatif otonom dalam proses-proses politik, (5) Walaupun negara merupakan yang paling utama dalam political community, berbagai komponen negara seperti individu, keluarga, asoiasi-asosiasi pribadi dan swasta mempunyai fungsi tersendiri di dalam organisasi secara keseluruhan.

Dari model-model teortis tentang negara di atas sangat tampak upaya untuk menguatkan masyarakat beradab (civil society) sesungguhnya berangkat dari kenyataan bahwa praksis model-model negara itu lebih didominasi wacana serba negara dan kecenderungan birokratisasi berlebih 
dalam kehidupan civil society. Hubungan antara negara dan civil society dalam konjungtur masa kini dikarakteristikan oleh ketergantungan yang terakhir kepada yang pertama. Memang belakangan untuk kasus Indonesia misalkan telah muncul gejala memudarnya korporatisme negara terhadap civil society. Akan tetapi yang muncul kemudian adalah suatu revolusi identitas (identity revolution) seperti kerusuhan etnik dan keagamaan yang sudah barang tentu bertentangan dengan gagasan masyarakat beradab itu sendiri. Berdasarkan kenyataan ini maka kebutuhan akan adanya peranan politik yang lebih luas dalam civil society serta mengarahkannya dalam suatu kehidupan kebangsaan yang lebih berkeadaban merupakan tantangan mendesak untuk mewujudkan kehdupan yang demokratis. Di sinilah kita memerlukan pemahaman yang utuh terhadap gagasan civil society.

\section{Civil Society dalam Demokratisasi Masyarakat}

Sejauh yang bisa diikuti dalam perdebatan mengenai civil society, kita sulit mencari padanan yang tepat untuk mengartikan terminologi ini. Beberapa istilah asing yang sepadan untuk mengartikan terminologi civil society dapat disebutkan di sini seperti; Koinonia Politike (Aristoteles), Societas Civilis (Cicero), Comonitas Civilis, Comonitas Politica, dan Societe Civile (Tocquiville), Burgerlische Gessellschaft (Hegel), Civil society dan Civitas Etat (Adam Ferguson). Sementara itu dalam bahasa Indonesia kita juga menemui banyak terjemahan untuk istilah yang sama seperti; Masyarakat Sipil (Mansour Fakih), Masyarakat Warga (Lembaga Etika Atmajaya dan Sutandyo Wignyosubroto), Masyarakat Kewargaan (Franz Magnis Suseno dan M. Ryaas Rasyid), Masyarakat Madani (Anwar Ibrahim, Nurcholish Madjid dan M. Dawam Rahardjo), dan "Civil society"—-tidak diterjemahkan-(Muhammad AS. Hikam).

Persoalan terminologi ini bukan suatu yang sederhana, sebab sebuah gagasan pasti menyimpan seperangkat tata nilai dan seperengkat sistem kebudayaan dimana gagasan itu lahir. Sementara kita tahu bahwa civil society-meminjam istilah Serif Mardin-merupakan impian dan aspirasi sejarah masyarakat eropa (Western dream and historical aspiration). Dari sinilah ada baiknya kita telusuri perbincangan teoritis mengenai civil society sehingga kita menemukan kandungan gagasan yang tepat dari istilah ini. 
Sebagaimana saya sebutkan di atas bahwa civil society adalah produk sejarah dan masyarakat Barat modern terutama sejak abad ke-17. Ia muncul bersamaan dengan proses modernisasi, terutama pada saat terjadi transformasi dari masyarakat feodal menuju masyarakat industri kapitalis. Civil society dengan demikian lahir ketika terjadi krisis tatanan sosial dan mulai surutnya pamor paradigma sosial yang ada saat itu. Krisis yang terjadi pada abad ke-17 seperti misalnya komersialisasi tanah, buruh dan modal, timbulnya ekonomi pasar, revolusi yang terjadi di Eropa, Amerika dan sebagainya, berakhir pada dipertanyakannya tatanan sosial dan konsep kekuasaan yang berlaku saat itu.

Dengan demikian civil society sebagai gagasan adalah anak kandung filsafat pencerahan (enlightment), yang meretas jalan bagi munculnya sekularisme sebagai pandangan dunia (world view) yang menggantikan agama dan sistem politik demokrasi menggantikan sistem monarki. Adam Furguson merupakan pemikir pencerahan yang mula-mula berbicara tentang civil society dalam konteks masyarakat Eropa abad 18. Demikian pula Rosseau dan Locke adalah pemikir-pemikir pencerahan yang mencoba memberikan landasan filosofis bagi munculnya sistem politik yang memberi posisi sentral pada kedaulatan individu, kesetaraan manusia dan persaudaraan umat manusia yang merupakan visi etis dari konsep civil society.

Dengan sangat rinci Dawan Rahardjo mengelompokkan konsep civil society pada lima model pemikiran. Pertama, civil society dipahami sebagai sistem kenegaraan. Artinya civil society identik dengan negara. Pemahaman demikian dikembangkan oleh Aristoteles (384-322 SM) Marcus Tullius Cicero (106-43 SM), Thomas Hobbes (1588-1679) dan John Locke (1632-1704). Dengan menggunakan istilah koinonia politike Aristoteles merujuk pada sebuah komunitas politik tempat warga dapat terlibat langsung dalam berbagai pertandingan ekonomi, politik dan pengambilan keputusan. Sementara Cicero dengan terminologinya societas civilis merumuskan pengertiannya sebagai komunitas yang mendominasi komunitas lain. Sedangkan Thomas Hobbes dan John Locke memahminya sebagai tahapan lebih lanjt dari natural society sehingga civil society sama dengan negara.

Kemunculan civil society, demikian menurut Hobbes bertujuan untuk meredam konflik dalam masyarakat, sehingga masyarakat tidak jatuh dalam chaos dan anarki. Karenanya, menurut Hobbes, civil society harus memiliki 
kekuasaan mutlak agar mampu sepenuhnya mengontrol dan mengawasi secara ketat pola interaksi (perilaku politik) setiap warga negara. Sementara bagi Locke, kehadiran civil society dimaksudkan untuk melindungi kebebasan dan hak milik setiap warga negara. Akibatnya civil society tidak boleh absolut. Ia harus membatasi peranannya pada wilayah yang tidak bisa dikelola masyarakat dan memberi ruang manusiawi bagi warga negara untuk memperoleh haknya secara adil dan proporsional. ${ }^{4}$

Kedua, versi Adam Fergusson. Fergusson memberi tekanan terhadap civil society sebagai sebuah "visi etis dalam kehidupan bermasyarakat". Ia menggunakan pemahaman ini untuk mengantisipasi perubahan sosial yang diakibatkan oleh revolusi industri dan munculnya kapitalisme. Industri dan kapitalisme, demikian menurut Fergusson, bertanggungjawab atas bertambah mencoloknya pembedaan antara yang publik dan privat. Dalam hal ini mucnulnya ekonomi pasar bisa melunturkan tanggungjawab publik dari warga karena dorongan pemuasan kepentingan pribadi. Oleh karena itu dengan konsep civil society Fergusson berharap kembalinya semangat publik untuk menghalangi munculnya despotisme. Sebab dalam civil society itulah solidaritas sosial muncul yang diilhami oleh sentimen moral dan sikap saling menyayangi serta saling mempercayai antar warga secara alamiah. Apa yang hendak ditekankan Fergusson adalah tentang perlunya tanggung jawab sosial di tengah menguatnya individualisme.

Ketiga, Thomas Paine, mulai memaknai civil society dalam posisi diametral dengan negara, bahkan dinilai antitesis negara. Dalam pandangan Paine negara harus dibatasi sampai sekecil-kecilnya, karena keberadaannya hanyalah keniscayaan belaka. Sebuah negara yang absah menurut Paine adalah perwujudan dari delegasi kekuasaan yang diberikan oleh masyarakat demi terciptanya kesejahteraan umum. Semakin sempurna suatu civil society semakin besar peluangnya untuk mengatur kehidupannya sendiri. Dengan pendapat ini Paine hendak menegaskan tentang adanya batas-batas yang mutlak menjadi wilayah otonom masyarakat dalam mana negara tidak sepantasnya masuk. Dari sinilah munculah pengertian civil society yang tidak lain adalah ruang dimana warga dapat mengembangkan kepribadian dan

4 Deliar Noor, Gerakan Modern Islam di Indonesia, (Jakarta: Pustaka Hidayah, 1987), h. 105- 
memberi peluang bagi pemuasan kepentingan secara bebas dan tanpa paksaan. Ia mengidealkan terciptanya suatu ruang gerak yang menjadi domain masyarakat dimana intervensi negara ke dalamnya merupakan sesuatu yang tidak sah. Karena itu civil society mestilah lebih kuat dan mengontrol negara demi kebutuhannya.

Keempat, civil society dimaknai sebagai "elemen ideologi kelas dominan". Konsep ini dikembangkan oleh Hegel dan merupakan kebalikan dari pemikiran Paine. Pemikiran Hegel didasarkan pada suatu pemahaman bahwa struktur sosial terbagi atas tiga entitas, yaitu keluarga, civil society dan negara. Keluarga adalah ruang sosialisasi pribadi sebagai anggota masyarakat yang bercirikan keharmonisan. Civil society merupakan lokasi atau tempat berlangsungnya pertarungan pelbagai kepentingan pribadi atau kelompok, terutama kepentingan ekonomi. Hegel tidak memandang civil society sebagai arena untuk praksis politik. Praksis politik menurut Hegal hanyalah monopoli negara. Sementara negara adalah representasi ide universal yang bertugas melindungi kepentingan politik warganya dan berhak penuh untuk intervensi terhadap civil society. Hal ini karena Hegel melihat civil society sebagai suatu entitas yang cenderung melumpuhkan dirinya sendiri (a self criping entity) dan secara konstan membutuhkan supervisi dan kontrol negara. Hegel Melihat adanya kebebasan mengembangkan aspirasi dan kepentingan yang berbeda yang menjadi karakter civil society sebagai sesuatu yang dapat menimbulkan kerawananan terhadap kohesi masyarakat. Dengan kemungkinan semacam ini maka menurut Hegel tindakan negara untuk menyusup ke dalam batas-batas tradisional dari civil society bukanlah sesuatu yang illegitimate. Civil society demikian menurut Hegal tidak dapat menjaga keberadaannya sendiri tanpa keteraturan politik, dan tanpa ketundukan pada pembinaan institusi yang lebih tinggi yaitu negara. Pendapat Hegal ini tampak sekali mencerminkan pandangan yang pesimistis terhadap civil society.

Kelima, teori yang melihat civil society sebagai entitas penyeimbang kekuatan negara. Pemikiran ini merupakan reaksi atas pemikiran Hegal yang dipelopori oleh Alexis de Toocquiville dan didukung oleh Robert Wuthnow. Pemikiran ini mengambil inspirasi dari pengalaman demokrasi di Amerika. Pengalaman itu menunjukan bahwa pada awal pembentukannya demokrasi di Amerika di jalankan lewat civil society yang berupa pengelompokan suka 
rela dalam masyarakat termasuk gereja dan asosiasi profesional yang concern membuat keputusan pada tingkat lokal dan menghindari intervensi negara.

Paradigma Tocquiville ini melihat civil society sesuai yang tidak apriori subordinatif terhadap negara. Ia bersifat otonom dan memiliki kapasitas politik cukup tinggi sehingga mampu menjadi kekuatan penyeimbang (balancing force) untuk menahan kecenderungan intervensionis negara. Civil society bahkan juga menjadi sumber legitimasi negara dan pada saat yang sama mampu melahirkan kekuatan kritis reflektif (refelective force) untuk mengurangi derajat konflik dalam masyarakat sebagai akibat formasi sosial modern. Dengan demikian civil society tidak hanya berorientasi kepada kepentingan sendiri, tetapi juga sensitif terhadap kepentingan publik.

Dari pengelompokan pandangan tentang civil society itu tampak sekali perkembangan pemikirannya sampai kepada pandangan yang mengungkapkan bahwa civil society adalah sebuah prasyarat yang dibutuhkan dalam proses demokratisasi. Hal ini dapat dipahami dari pemikiran civil society yang paling kontemporer yang memandang bahwa civil society adalah wilayah kehidupan sosial terorganisir yang cukup mandiri dan kuat berhadapan dengan negara, berswasembada dan swadaya, namun tetap berpegang pada norma atau nilai-nilai hukum, tidak menghalangi negara dalam menjalankan perannya. Dalam civil society masyarakat memiliki berbagai institusi, lembaga atau organisasi otonom yang memiliki bargaining power dan bargaining positition yang seimbang dengan pemerintah dalam penentuan kebijaksanaan, adanya kesadaran masyarakat atas hak dan kewajibannya, terjadi proses gusur menggusur, pengaruh mempengaruhi dan ada unsur pengawasan dan pengimbangan dari masyarakat terhadap kekuasaan negara. Dengan begitu, negara akan menjalankan fungsinya yaitu menjamin hak milik, kehidupan, pluralitas dan kebebasan para anggotanya dan tidak mendominasi serta mengatomisasi masyarakat.

\section{Islam dan Civil Society}

Apabila kebutuhan menumbuhkan civil society mencakup kemampuan revitalisasi organisasi-organisasi sosial (termasuk yang berbasis agama) berhadapan dengan kekuatan negara dalam menciptakan praktik-praktik sosial politik, maka sebagaimana telah ditunjukan oleh kajian-kajian yang saya sebutkan di awal agama dapat memiliki peran penting. Agama dapat memainkan 
peranan penting sebagai sumber diskursus dan praktek-praktek sosial politik yang penting dari civil society bersama dengan struktur makna lainnya.

Sebagaimana diungkapkan oleh Hikam agama telah memainkan peranan besar dalam merangsang aksi-aksi sosial dan politik untuk melawan kekuasaan politik dan ideologi negara yang sangat dominan. Selama periode kolonial misalkan, banyak sekali gerakan sosial yang berdasarkan agama ditujukan untuk mengingkari hegemoni negara dan menegaskan ruang sosial dan politik mereka sendiri. Di Indonesia umpamanya, banyak gerakan millenarian didasarkan pada ajaran eskatologis agama, misalnya seperi Imam Mahdiisme atau gerakan ratu adil yang semuanya bertujuan untuk menegakkan sebuah masyarakat yang ideal, bebas dari ketidakadilan sosial dan penindasan politik yang dilakukan oleh negara. Kendatipun gerakan-gerakan ini sebagian besar tidak terorganisasi dengan baik, tak sistematis dan karenanya dengan mudah bisa dipatahkan oleh negara, tapi signifikansinya sebagai perlawanan sosial dan civil society tidak bisa diabaikan begitu saja. Gerakangerakan itu memperlihatkan kemampuan civil society untuk melawan ideologi dominan dan praktek-praktek negara.

Penguatan civil society yang diperankan oleh gerakan-gerakan keagamaan memang mengalami pasang surut berhadapan dengan negara dan menjumpai dinamika internalnya sendiri. Setalah mengalami proses peninandasan yang panjang selama pemerintahan Orde Baru sehingga gerakan keagamaan relatif "mandul" dari sudut kontribusinya terhadap civil society kini tampak gairah baru dalam gerakan-gerakan keagamaan. Hingga kini kita bisa mencatat dua kemungkinan dari gerakan keagamaan kontemporer yang akan menjadi penentu apakah gerakan itu akan memberi kontribusi bagi pengembangan civil society. Kedua gerakan itu bisa dirujuk pada pengertian gerakan keagamaan bisa menjadi gerakan sosial yang reaksioner dan reformis. Gerakan keagamaan sangat mungkin menjala gejala reaksioner jika gagal memahami persoalan sosial politik yang mendalam pada civil society atau mengembangkan diri lebih jauh dengan klaim keagamaan yang eksklusif mengenai kebenaran. Tetapi gerakan keagamaan juga bisa mewakili gerakan sosial yang sejati jika ia mampu mengartikulasikan proses sosial politik yang mendasar dan menjawab persoaloan sosial politik yang ada. Gerakan ini harus menyediakan alternatif yang tepat bagi masyarakat pada umumnya, bukan hanya komunitasnya sendiri. 
Fundamentalisme sebagai gerakan keagamaan dengan demikian justru mewakili gerakan reaksioner karena tendensinya untuk memonopoli klaim kebenaran sehingga gagal memasukkan interpretasi yang berbeda yang berasal dari struktur makna lainnya. Pada gilirannya gerakan semacam ini hanya akan menciptakan suatu interpretasi monolitik mengenai fenomena sosial politik dan akhirnya mendorong timbulnya jenis lain dari sistem politik otoriter yang jelas berseberangan dengan gagasan civil society.

Dengan demikian dapat disimpulkan bahwa agama mampu menyediakan alternatif tumbuhnya civil society yang sehat dan menyumbangkan keterbukaan politik di masa depan. Sebagai struktur makna yang khas, agama tidak hanya bisa dianggap sebagai antitesis terhadap modernitas, tetapi juga sebagai kritik terhadap interpretasi dominan atas modernitas. Sebagai sistem makna ia bisa digunakan sebagai sumber dari mana diskursus sosial dan politik lainnya dikembangkan dan diartikulasikan oleh civil society untuk menghadapi dominasi negara. Namun demikian kita diingatkan oleh Hikam bahwa gerakan keagamaan sebagai suatu aksi sosial politik juga menghadapi bahaya, yakni timbulnya suatu diskursus yang monolitik yang bisa melahirkan struktur politik yang otoriter. Dengan demikian persoalannya adalah tergantung bagaimana agama diinterpretasikan dan diwujudkan dalam praksis sosial politik.

\section{E. Gerakan Islam Kultural}

Isu besar yang dijadikan perhatian awal pada penelitian ini ialah Islam kultural yang merupakan perimbangan dari istilah Islam Politik. Lebih spesifik Islam kultural ini tampak dalam aktivitas kelompok civil Islam seperti wadah-wadah gerakan civil society yang ada di NU (Lapkesdam) dan Muhammadiyah (Jaringan Intelektual Muda Muhammadiyah/JIMM) maupun di luar keduanya Jaringan Islam Liberal (JIL) dan Jaringan Islam Emansipatoris (JIE) milik P3M. Sebagai salah satu dari bentuk gerakan Islam maka Islam kultural menyangkut figur dan gagasan serta paradigma dan strategi. Untuk memperoleh data sehubungan dengan permasalahan di atas, dilakukan dengan tiga cara. Pertama, berdasarkan pada kajian dokumen-dokumen tertulis (berupa buku, jurnal artikel dan surat kabar). Kedua, wawancara. Metode wawancara dilakukan dengan cara yaitu (a) wawancara personal, 
dan (b) wawancara berkelompok. Wawancara personal adalah wawancara dengan sejumlah informan yang terpilih sebagai key person gerakan Islam kultural. Para informan yang dipilih ialah: (i) tokoh formal, (ii) tokoh informal.

Wawancara berkelompok dimaksudkan sebagai FGD (Focus Group Discussion). Karena gerakan Islam menyangkut banyak subjek dan kelompok yang terlibat di dalamnya, maka FGD dilakukan dalam rangka mengetahui dan merumuskan platform yang dimiliki oleh masing-masing kelompok. Analisis dilakukan didasarkan pada analisis kualitatif. Ciri dari analisis seperti ini ialah menitikberatkan pada pemahaman terhadap data-data yang dikumpulkan dengan cara klasifikasi, kategorisasi, dan taksonomi, untuk ditemukan pola-polanya dan penjelasan teoritiknya berdasarkan pada perspektif masyarakat yang dipelajari.

\section{F. Islam, Pluralisme dan Demokrasi}

Peristiwa 11 September 2001 bukan saja memunculkan perhatian akan bahaya terorisme global, tetapi juga mengakibakan munculnya pertanyaanpertanyaan tajam dan mendalam mengenai apakah Islam selaras dengan pluralisme dan demokrasi. Salah satu tema penting daam membicarakan gerakan Islam adalah pertarungan antara hati dan pikiran berkembang melanda dunia Islam, yaitu konflik antara Muslim santun yang mendukung pluralisme dan demokrasi melawan mereka yang bersikeras bahwa berbagai institusi yang ada dewasa ini merupakan antitesis Islam. Dengan jumlah 1,3 milyar umat Islam di dunia, maka persaingan dalam gerakan Islam ini akan sangat berpengaruh terhadap peristiwa-peristiwa politik dunia di abad ke-21.

Buku Remaking Muslim Politics: Pluralism, Contestation, Democratization yang dieditori oleh Robert W. Hefner memuat 20 artikal karya berbagai spesialis dari berbagai negara (Bahman Baktiari, Thomas Barfield, John R. Bowen, Dale F. Eickelman, Robert W. Hefner, Peter Mandaville, Augustus Richard Norton, Gwenn Okruhlik, Michael G. Peletz, Diane Singerman, Jenny B. White, and Muhammad Qasim Zaman). Secara khusus karya ini menguji asal-usul perkembangan Islam sipil demokratik (civil demokratic Islam) dan prospeknya untuk jangka panjang, juga implikasinya bagi dunia Barat. Buku ini merupakan pelajaran yang sangat bermanfaat bagi pemahaman kita mengenai agama dan politik pada masa modern. 
Meskipun dilihat oleh para penentangnya sebagai produk dari gagasangagasan politik yang diciptakan di dunia Barat, Islam sipil demokratik merepresentasikan sebuah sebuah politik asli pribumi Islam (indigenious politics) yang berusaha untuk membangun sebuah Islam modern yang khas. Di negara-negara seperti Turki, Iran, Malaysia dan Indonesia, Islam sipil demokratik sedang menjadi kekuatan poltik mayoritas. Di sisi lain pengaruhnya juga sangat jelas dalam usaha-usahanya untuk merancang dasar-dasar Islam bagi hak-hak perempuan, toleransi agama dan demokrasi kemasyarakatan. Dimanapun Islam sipil demokratik telah memunculkan perlawanan dari kelompok-kelompok keagamaan yang konservatif. Buku Remaking Muslim Politics yang merupakan rangkaian artikel berbagai sarjana dari studi-studi kasus, membuka cahaya baru tentang proses demokrasi sebagai cerminan dari ekperimen dan pengalaman berbagai negera belahan dunis Islam mulai dari Mesir, Turki, Saudi Arabia, hingga Iran, Afganistan, Malaysia dan Indonesia.

Penelitian Robert W. Hefner berjudul Civil Islam: Muslims and Democratization in Indonesia 5 adalah karya mutakhir mengenai gerakangerakan di Indonesia termasuk di dalamnya gerakan Islam dalam proses demokrasi di Indonesia. Melalui perspektif “antropologi demokrasi” Hefner mematahkan banyak hipotesis yang dikembangkan para pemerhati demokrasi mengenai ketaktersediaan modal kultural bagi dunia Islam untuk mengembangkan demokrasi sebagai gagasan yang lahir dari peradaban Barat. Hefner bahkan telah menunjukkan adanya modal sosial dari sejarah Islam di Indonesia bagi sumbangan untuk demokrasi. Dalam kaitan ini Hefner merujuk pada proses transisi dari kekuasaan Orde Baru melalui proses reformasi yang telah di dorong oleh kesatuan kekuatan Islam untuk bersepakat dalam mendorong bagi suatu proses transisi demokratis dan kedamaian masyarakat sipil. Namun Hefner juga mencatat adanya titik lemah gerakan Islam yang bisa memukuk demokrasi itu sebagaimana tercermin dalam kekerasan-kekerasan gerakan etnik dan keagamaan di Indonesia yang membangkitkan semangat primordialisme.

5 Robert W. Hefner, Civil Islam: Muslim and Democratization in Indonesia, (Princeton University Press, 2000). 
Kita juga bisa mencatat karya-karya-yang kini telah menjadi klasiktentang relasi gerakan keagamaan baik tradisional maupun modern dengan dinamika sosial politik seperti The Modernis Muslim Movement in Indonesia 1900-1942 karya Deliar Noer, The Struggle of Islam in Modern Indonesia karya B.J. Boland, School and Politics: The Kaum Muda Movement in West Sumatra 1927-1933 karya Taufik Abdullah, Traditional Authority, Islam and Rebellion A Study of Indonesian Political Behevior karya Karl D. Jackson, karya James Peacok, Purfying the Faith; The Muhammadiyah Movement in Indonesian Islam. Sedangkan kajian mengenai relasi gerakan-gerakan keagamaan tradisional dengan dinamika sosial politik bisa dilihat pada beberapa karya seperti Radical Traditionalism karya Greg Barton \& Gerg Fealy, NU vis a vis Negara karya Andree Fealard.

Banyaknya karya-karya yang mengupas hubungan antara agama dengan dinamika sosial politik (relasi agama dan negara) itu sekaligus menandai pudarnya diskurus sosial politik dominan yang didasarkan atas paradigma modernisasi. ${ }^{6}$ Dengan paradigma modernisasi kesadaran rasional dianggap sebagai satu-satunya penentu hubungan sosial politik dan ekonomi dalam diskursus negara (state) maupun civil society. Sementara "kesadaran agama" dipertentangkan dengan diskursus itu. ${ }^{7}$

Krisis terhadap paradigma modernisasi dewasa ini agaknya memberi kesempatan untuk dibukanya kembali wacana relasi agama dalam konteks kehidupan negara modern. Bahkan agama kemudian diasumsikan menjadi penentu utama percaturan dan dialektika peradaban. Karya Samuel P. Huntington The Clash of Civilzation yang menggemparkan itu sekaligus mengingatkan kita bahwa dunia Pascamodern akan ditentutkan oleh agama sebagai unsur primer peradaban yang diperkirakan akan mengalami benturan-benturan. Dari sinilah kemudian mencari kemungkinan dan bentuk relasi yang tepat antara agama, negara dan civil society menjadi keharusan.

Studi mengenai gerakan Islam di Indonesia sebenarnya telah banyak dilakukan. Studi itu memberi bobot perhatian yang berbeda-beda dalam

6 Lihat Bassam Tibbi, Krisis Peradaban Modern, (Bandung: Mizan, 1994).

7 Donald Eugne Smith telah menunjukan pentingnya peran agama di dalam politik dan perubahan sosial terutama dalam kasus negara-negara dunia ketiga seperti Myanmar, Pakistan, maupun Indonesia. Lihat Donald Eugne Smith, Religion, Politic and Social Change in the Three World, (New York: A Free Press Paperback Macmillan Publising Co., 1974). 
melihat gerakan Islam tersebut. Cristine Dobbin ${ }^{8}$ misalkan telah menelusuri gerakan Islam di Sumatera. Dobbin telah menunjukan bahwa corak pemikiran keagamaan kalangan modernis di Indonesia tidak sepenuhnya sama dengan para tokoh modernis Timur Tengah. Sebagian dari pemikiran kalangan modernis justru dekat dengan khazanah Wahabiyah dan Ibn Taimiyah yang telah masuk di Indonesia sejak abad ke-19. Dalam kasus Sumatera Barat pemikiran Wahabi telah melahirkan pergolakan sosial politik dengan terpilahnya masyarakat setempat ke dalam Kaum Adat dan Kaum Padri. Kelompok pertama mewakili model keberagamaan tradisional, sedangkan yang kedua mewakili kaum pembaharu. Kajian Dobbin dengan demikian menghasilkan sebuah perspektif dikotomik mengenai gerakan Islam di Indonesia (Tradisional dan Modern).

Deliar Noer ${ }^{9}$ telah melakukan kajian mengenai gerakan Islam pada masa kolonial dan revolusi. Melalui karyanya Deliar Noer lebih memaparkan secara kronologis tentang latar belakang munculnya gerakan modern di Indonesia serta proses berdiri dan berkembangnya organisasi-organisasi Islam di Indonesia dengan agenda gerakannya masing-masing. Buku Deliar kemudian menjadi yang cukup otoritatif mengenai gerakan Islam modern di Indonesia.

Selain penelitian-penelitian yang memberi perhatian secara umum terhadap gerakan Islam juga terdapat karya-karya yang secara spesifik membahas organisasi sosial keagamaan. Alfian misalkan memberikan perhatian khusus pada gerakan Islam modern dalam kaitannya dengan politik di Indonesia dalam disertasinya pada Universitas Wisconsin tahun 1969, "Islamic Modernism in Indonesian Politics; The Muhammadijah during the Colonial Periode. Sementara karya Choirul Anam menguraikan secara spesifik dan kronologis tentang organisasi tradisional Nahdlatul Ulama. Karya Anam Nahdlatul Ulama merupakan penelusuran lengkap tentang sejarah pertumbuhan NU.

Dari sebagian karya-karya mengenai gerakan Islam di Indonesia itu kita mendapatkan kategori dan pembilahan gerakan Islam di Indonesia. Istilah "modern" dan "tradisional" merupakan hasil yang diperoleh melalui kajian-

\footnotetext{
${ }^{8}$ Cristine Dobbin, Islamic Revivalism in a Changing Peasant Economy: Central Sumatera 17841848, (London: Curzon Press, 1983).

${ }^{9}$ Deliar Noer, Gerakan Modern Islam di Indonesia 1900-1942, (Jakarta: LP3ES, 1988).
} 
kajian gerakan Islam tersebut. Penelitian itu juga menujukan kompleksitas tradisionalisme maupun modernisme Islam di Indonesia yang pada gilirannya akan terekspresi ke dalam agenda dan setting gerakan yang dilakukan oleh gerakan-gerakan Islam.

Selain kajian terhadap perkembangan gerakan Islam di Indonesia yang sebagian telah disebutkan di atas, terdapat juga kajian mengenai Islam dan negara maupun Islam dan civil society. Untuk studi tentang Islam dan negara diantaranya telah dilakukan oleh Abdul Munir Mulkan dalam karyanya Runtuhnya Mitos Politik Kaum Santri. Studi ini berhasil merekonstruksi model hubungan antara Islam dan kekuasan di Indonesia. Satu hal yang hendak dipecahkan dalam studi Mulkhan adalah mengenai mitos pembangkangan yang melekat dalam tradisi pergulatan politik Islam dan kekuasaan di Indonesia. Pengalaman politik Islam di Indonesia pada tahun 1990-an. Menurut Mulkhan tekah menunjukan model lain mengenai hubungan Islam dan kekuasaan yang mencerminkan integrasi birokratik sebagai model akamodasi antara Islam dan negara.

Dalam sejarah perpolitikan di Indonesia, hubbungan antara Islam dan negara memang tidak mencerminkan suatu gambaran yang monolitik. Terdapat berbagai model hubungan baik yang didorong oleh model pemahaman keislaman maupun pengalaman sejarah politik Islam di Indonesia. Buku Islam dan Negara karya Bahtiar Efendi telah menunjukan kerangka dan model teritik tentang hubungan antara Islam dan negara di Indonesia. Model ini digali dari pengalaman praktek sosial politik masyarakat Islam di tengah realitas masyarakat dan aspirasi politik Indonesia yang majemuk. Secara mendalam Bahtiar telah menyajikan lima model teritik yang dihasilkan para peminat kajian Islam dan negara di Indonesia: (1) dekonfensionalisasi Islam, (2) domestikasi Islam, (3) skismatik dan aliran, (4) trikotomi, dan (5) Islam kultural. Dengan mempertimbangkan praktek politik Islam yang selalu menemui jalan buntu secara sederhana kemudian Bahtiar merumuskan sebuah model taoritik mengenai Islam dan Negara yang disebutnya sebagai teologi politik inklusif sebagai jalan keluar.

Sebagai sebuah diskursus yang paralel dengan perkembangan demokrasi, hubungan antara Islam dan civil society juga telah banyak dilakukan dalam kajian mengenai Islam kontemporer. Serif Mardin dalam salah satu 
tulisannya Civil society and Islam sebagaimana dimuat dalam buku Civil society yang diedit oleg John A. Hall telah melakukan studi perbandingan terhadap masyarakat Timur Tengah dan Turki. Menurut Mardin, masyarakat Muslim, khususnya yang diperlihatkan oleh negara-negar Timur Tengah, kurang memiliki prasyarat bagi terbentuknya civil society. Ada beberapa faktor penghambat civil society yang ditnjukkan oleh Mardin seperti; tidak adanya nilai individualisme, masih kuatnya kepemimpinan kharismatik, kurangnya ikatan hukum, dan belum terbentuknya komunitas yang plural. Namun demikian Mardin tidak menafikan secara normatif Islam memuat nilai-nilai yang sesuai dengan gasan civil society. Karya Serif Mardin ini berhasil menunjukan adanya tradisi sosial dan politik masyarakat Islam yang tidak selalu sesuai dengan wawasan normatif mengenai civil society. Petunjuknya mengenai ketiadaan prasyarat sosial bagi civil society dengan merujuk Timur Tengah dan Truki itu paling tidak mendorong bagi dilakukannya penelitian bagi kawasan lain dunia Islam yang telah mengekspresikan praktek sosial politik Islam.

Sadar akan apa yang disimpulkan oleh Serif Mardin Handro Prasetyo dan Ali Munhanif dengan tim peneliti Pusat Pengkajian Islam dan Masyarajat (PPIM) Jakarta untuk melakukan riset atas wacana civil society di Indonesia dalam sebuah riset mengenai Islam dan Pandangan Muslim Indonesia tentang civil society. Penelitian itu menunjukan adanya perumusan konsep dan penggunaan yang berbeda dalam pemikiran dan agneda mulsim di Indonesia mengenai civil society. Ada dua konsep yang dugunakan oleh masyarakat mulsim Indonesia untuk menerjemahkan konsep civil society yaitu masyarakat civil dan masyarakat madani. Menindaklanjuti apa yang telah diteliti oleh Ahmad Baso yang menunjukan adanya wacana ideologis pertarungan civil society versus masyarakat madani Hendro dan Ali Munhanif menunjukan adanya perbedaan konseptualisasi dan agenda civil society antara golongan tradisional dan modern. Kaum tradisional merumuskan gagasan civil society dengan masyarakat sipil dengan agenda utamanya perlawanan terhadap negara, tidak semata-mata sebagai suatu istilah yang diambil secara kebetulan, tetapi juga dipengaruhi oleh kosep keagamaan dan pengalaman sosial politik yang telah dijalaninya. Sementara kalangan modernis menggunakan istilah masyarakat madani untuk menerjemahkan 
gagasan yang sama. Cara kaum modernis menerjemahkan civil society dan merumuskan agenda kerjanya juga sebagaimana kaum tradisionalis terkait erat dengan wacana keberagamaan yang dikembangkan dan praktek sosial politik yang telah dilakukan yang relatif terakomodasi dalam panggung politik kenegaraan.

Penelitian Hendro dan Ali Munhanif, telah berhasil menunjukan setting agenda dan latar keberagamaan dan politik dalam perbedanaan pandangan mengenai civil society di Indonesia. Namun demikian suatu hal yang belum ditemukan adalah mengenai prasyarat sosial maupun kultural bagi pembentukan negara demokratis dan penguatan civil society di Indonesia. Tindak lanjut untuk mengkaji agenda ini menjadi penting setidaknya untuk menggali akar-akar kebangkitan gerakan religio kultutal di Indonesia dan kemungkinan pengembangannya bagi penciptaan negara demokratis dan penguatan civil society.

\section{G. Akar Islam Kultural}

Istilah Islam kultural sering digunakan untuk menyebut gerakan Islam yang membedakannya dari Islam struktural. Keduanya merupakan penanda bagi apa yang disebut model gerakan Islam Indonesia pada tahun 1980-an. Keduanya adalah model dari pilihan strategi arus atas dan strategi arus bawah yang mewakili dua eksonen penting saat itu yaitu Amien Rais dan Abdurrahman Wahid sebelum kedunya masuk ke gelanggang politik secara langsung. Sebagai pilihan strategi maka sudah pasti ditentukan Islam kultural dan Islam struktural itu ditentukanberdasarkan pembacaan terhadap makna Isam dalam kaitannya realias sosio-kultural dan realitas sosial politik yang dihadapi.

Saya ingin menarik diskusi mengenai Islam kultural itu bukan semata daam perbandingannya dengan Islam struktural yang diambil secara bebeda oleh Amien ataupun Gus Dur, oleh kalangan modernis atupun tradisionalis. Karena dalam kenyataannya strategi kultural dan kultural dikhotomi strategi itu tidak terjadi. Ambisi struktural kini tidak hanya dominasi kaum modernis tepai juga kalangan tradisionalis. Sebaliknya strategi kultural kini juga mulai dilirik oleh kalangan modernis dengan konsepsi dakwah kulturalnya. Terbukanya ruang politik pasca reformasi 1998 telah membuka kemungkinan yang sangat luas bagi pencapaian posisi-posisi struktural dalam kehidupan 
negara oleh para politisi Muslim. Bahka bisa dikatakan hilangnya restriksi terhadap gerakan-gerakan Islam telah mendorong aktivis Muslim Indonesia memainkan strategi total politik dan menghasilkan posisi strategi baik di badan-badan pemerintahan maupun dilegislatif.

Persoalannya adalah sejauhmana capaian politik sturktural itu berdampak bagi pengangangkatan harkat dan martabat serta kesejahteraan rakyat? Sejauhmana kekuasaan itu berpihak kepada rakyat dan tidak sematamata menguntungkan segelintir orang yang berkuasa? Ya strategi struktural tampaknya memiliki keterbatasannya sendiri. Posisi-posisi struktural itu sangat terbatas. Di sana ada segenggam kuasa tapi disana pula ada seabrek masalah yang melilitnya. Dengan kondisi semacam ini maka kekuasaan cenderung melayani dirinya sendiri, memecahkan masalah kekuasaan itu sendiri dan bukan melayani dan memecahkan masalah yang terus berkembang di tengah-tengah masyarakat. Kapasitas para pengelola pun sangat terbatas sehingga alih-alih berkuasa untuk memperbaiki negeri ini sebaliknya yang terjadi adalah bancakan di sana-sini. Bahaya pun muncul, negeri kita terancam bangkrut. Ketidakpercayaan masyarakat terhadap pemerintah meluas dimana-mana. Dan bahaya yang yang paling dasar adalah ketika ketidakpercayan itu bukan semata-mata perkara politik, tetapi lebih karena marginalisasi yang berkangsung terus menerus yang berakibat pada hilangnya kapasitas dan kemandirian masyarakat. Di sinilah signifikansi kita tentang revitalisasi Islam kultural sebagai gerakangkan terus menerus tanpa akhir. Suatu gerakan Islam yang integratif dengan denyut nadi kebudayaan lokal dan masyarakat bawah.

Adalah Abdurrahman Wahid yang memperkenalkan gerakan Islam kultural yang disebutnya sebagai pribumisasi Islam. Apa yang hendak ditutuju melalui gerakan ini adalah bagaimana mengadaptasi konsep-konsep ajaran universal Islam dengan nilai-nilai kebudayaan lokal yang tumbuh dalam masyarakat. Suatu pemahaman Islam yang diracik berdasarkan dialog antara Islam dan realitas budaya, dan suatu Islam yang respek terhadap kultur lokal bukan Islam Islam abusolitistik model Arab yang memaksakan hukum-hukum dan tidak toleran terhadap kebudayaan lokal. Sejauh menyangkut pengalaman-pengalaman dan praktek-praktek keberislaman, maka Islam Arab tidak bisa diuniversalkan untuk kemudian diterapkan di tempattempat lain, tanpa terlebih dahulu dilakukan proses penyaringan dan 
kontekstualisasi. Islam Arab demikian menurut para pendukung gagasan Islam peribumi ini, adalah salah satu jenis dari sekian banyak jenis Islam yang lain. Semua jenis keislaman itu berkedudukan setara, yang satu tidak lebih unggul dari yang lain hanya karena ia muncul di Arab. Demikian pula yang satu tidak bisa dianggap rendah karena ia hidup dan berkembang di Indonesia. ${ }^{10}$

Sebagaiamana telah diuraiakan sebelumnya bahwa pasca reformasi 1998, keberagamaan masyarakat Islam Indonesia telah banyak mengalami pergeseran yang ditandai dengan pudarnya tradisionalisme dan modernisme disatu sisi dan menculnya, literalisme radikal dan Islam liberal pada sisi yang lain. Radikalsme Islam bahkan telah menyita perhatian pada beberapa tahun belakangan ini. Radikalisme Islam menyentak kesadaran banyak orang tentang bahaya Islam dan menghilangkan gambaran mengenai keramahan, toleransi, kedamaian yang selama ini menjadi citra bagi wajah Islam Indonesia.

NU dan Muhammadiyah yang selama ini menjadi warna dari keberagamaan (Islam) di Tanah Air mulai mendapatkan pesaing baru dari gerakan otentifikasi dan universalisme di dalam gerakan baru Islam. Kalau dahulu masyarakat Muslim berafiliasi secara kultural dan organisatoris dengan NU dan Muhammadiyah, sekarang afiliasinya mulai tersebar ke berbagai organisasi Islam yang lahir belakangan ini. Ironisnya, gerakan baru Islam ini menampilkan wajah keberagamaannya yang intoleran dan keras. Gerakan baru keagamaan tampaknya tidak mengambil ideologi keagamaan yang toleran dan pluralis untuk memberikan tempat bagi perbedaan, kemajemukan, dan keanekaragaman budaya.

Bahkan, ada keyakinan kuat mereka untuk menyeragamkan pandangan keagamaan menjadi satu. Karena itu, yang selalu mereka usung adalah proyek otentifikasi Islam atau pemurnian Islam untuk menciptakan sistem sosial yang sama, seperti yang pernah terjadi di dalam sejarah Islam klasik. Negara Islam dan pemberlakuan syariat Islam secara total selalu menjadi cita-cita luhur mereka dalam menggerakkan jaringan di seluruh belahan

${ }^{10}$ Abd Moqsith Ghazali \& Mustafa Basyir Rasyad “Islam Pribumi: Mencari Model Kebersialam ala Indonesia” dalam Komaruddin Hidayat dan Ahmad Gaus AF (ed.) Menjadi Indonesia: 13 Abad Eksistemsi Islam di Bumi Nusantara, (Bandung: Mizan, 2006), h. 658-659. 
dunia. Otentifikasi Islam Dalam konteks inilah, proyek otentifikasi Islam yang diusung oleh gerakan baru Islam mengandaikan pandangan dunia (world view) yang kukuh, "Islam sebagai kerangka normatif ajaran yang baku, tak berubah, dan kekal." Karena itu, seluruh bangunan tekstualnya mesti merujuk pada sendi-sendi dasar yang termaktub dalam teks Kitab Suci dan apa yang pernah diajarkan Nabi SAW di Mekah dan Madinah sebagai basis geografis lahirnya Islam. Hal ini didasarkan pada realitas Islam sebagai agama yang lahir di masa Rasulullah tanpa mengalami proses historisasi ajaran. Islam dipandang sebagai ajaran agama yang selesai di masa itu dan tidak boleh mengalami modifikasi, kontekstualisasi, ataupun perubahan.

Di sinilah otentifikasi Islam menjadi trademark ajaran yang paling benar dan dapat diaplikasikan di seluruh belahan dunia. Sehingga, di luar geografis itu mesti meniru model yang sudah terjadi di masa Rasulullah. Pada gilirannya, Islam yang di sana dipandang sebagai Islam otentik, sedangkan Islam di wilayah lainnya bukan Islam yang otentik, 'Islam periferal', yang jauh dari karakter aslinya. Itu sebabnya, sikap keberagamaan (Islam) di wilayah Nusantara yang telah mengalami proses akomodasi kultural dianggap bukan Islam otentik karena sudah berubah dari ajaran aslinya. Pada gilirannya, ini membawa perubahan pola pikir keberagamaan dari Islam lokal menjadi universalitas Islam dalam praktik ajarannya. Akibatnya, tuduhan sinkretisme dan bidah telah merusak warna keaslian bangsa toleran yang sudah diwariskan nenek moyang sebagai identitas kultural. Islam di wilayah Nusantara sudah tidak lagi menampakkan wajah toleran dan damainya, karena sudah dipenuhi dengan gerakan pemurnian (otentifikasi) yang tidak mengakui multiinterpretasi Islam sebagai agama yang mengalami proses historisasi. Pada ujung-ujungnya yang terjadi justru radikalisme agama atau bahkan aksi terorisme. Wajah Islam seperti inikah yang akan tetap kita pertahankan sekarang ini?

Tentu saja tidak! Karena Islam mesti menjadi ajaran yang menumbuhkan pesan-pesan damai dalam kehidupan sosial. Islam pribumi Di sinilah, gagasan 'Pribumisasi Islam' yang pernah dilontarkan Abdurrahman Wahid patut kita lanjutkan kembali untuk menjawab problem radikalisme Islam. Dalam "pribumisasi Islam" tergambar bagaimana Islam sebagai ajaran yang normatif berasal dari Tuhan diakomodasikan ke dalam kebudayaan yang berasal dari manusia tanpa kehilangan identitasnya masing-masing. 
Sehingga, tidak ada lagi pemurnian Islam atau proses menyamakan dengan praktik keagamaan masyarakat Muslim di Timur Tengah. Bukankah Arabisasi atau proses mengidentifikasi diri dengan budaya Timur Tengah berarti tercabutnya kita dari akar budaya kita sendiri?

Dalam hal ini, pribumisasi bukan upaya menghindarkan timbulnya perlawanan dari kekuatan budaya-budaya setempat, akan tetapi justru agar budaya itu tidak hilang. Inti 'Pribumisasi Islam' adalah kebutuhan bukan untuk menghindari polarisasi antara agama dan budaya, sebab polarisasi demikian memang tidak terhindarkan. Pada konteks selanjutnya, akan tercipta pola-pola keberagamaan (Islam) yang sesuai dengan konteks lokalnya, dalam wujud 'Islam Pribumi' sebagai jawaban dari 'Islam Otentik' atau 'Islam Murni' yang ingin melakukan proyek Arabisasi di dalam setiap komunitas Islam di seluruh penjuru dunia. 'Islam Pribumi' justru memberi keanekaragaman interpretasi dalam praktik kehidupan beragama (Islam) di setiap wilayah yang berbeda-beda.

Dengan demikian, Islam tidak lagi dipandang secara tunggal, melainkan beraneka ragam. Tidak ada lagi anggapan Islam yang di Timur Tengah sebagai Islam yang murni dan paling benar, karena Islam sebagai agama mengalami historisitas yang terus berlanjut. 'Islam Pribumi' sebagai jawaban dari Islam otentik mengandaikan tiga hal. Pertama, 'Islam Pribumi' memiliki sifat kontekstual, yakni Islam dipahami sebagai ajaran yang terkait dengan konteks zaman dan tempat. Perubahan waktu dan perbedaan wilayah menjadi kunci untuk menginterpretasikan ajaran. Dengan demikian, Islam akan mengalami perubahan dan dinamika dalam merespons perubahan zaman.

Kedua, 'Islam Pribumi' bersifat progresif, yakni kemajuan zaman bukan dipahami sebagai ancaman terhadap penyimpangan terhadap ajaran dasar agama (Islam), tetapi dilihat sebagai pemicu untuk melakukan respons kreatif secara intens. Ketiga, 'Islam Pribumi' memiliki karakter membebaskan. Dalam pengertian, Islam menjadi ajaran yang dapat menjawab problemproblem kemanusiaan secara universal tanpa melihat perbedaan agama dan etnik. Dengan demikian, Islam tidak kaku dan rigid dalam menghadapi realitas sosial masyarakat yang selalu berubah. Dalam konteks inilah, 'Islam Pribumi' ingin membebaskan puritanisme, otentifikasi, dan segala bentuk pemurnian Islam sekaligus juga menjaga kearifan lokal tanpa menghilangkan 
identitas normatif Islam. Karena itulah, 'Islam Pribumi' lebih berideologi kultural yang tersebar (spread cultural ideology), yang mempertimbangkan perbedaan lokalitas ketimbang ideologi kultural yang memusat, yang hanya mengakui ajaran agama tanpa interpretasi. Sehingga dapat tersebar di berbagai wilayah tanpa merusak kultur lokal masyarakat setempat. Dengan demikian, tidak akan ada lagi praktik-praktik radikalisme yang ditopang oleh paham-paham keagamaan ekstrem, yang selama ini menjadi ancaman bagi terciptanya perdamaian.

Selain argumentasi di atas, Islam kultural juga memiliki landasan historis yang kokoh dalam proses perkembangan Islam Nusantara. Sejarah membuktikan bahwa perkembangan Islam di Indonesia bukanlah sebuah proses yang monolitik yang berjalan melalui proses tunggal, diterima dan diinterpretasi secara tunggal pula. Sebaliknya sebagaimana studi yang dilakukan oleh Djoko Surjo, dkk. (2001, proses penerimaan dan interpretasi Islam Nusantara menunjukkan keanekaragaman mode of transfer, mode of acceptence atau mode of translation. Yang semuanya mempengaruhi formasi sosial politik dan kultural masyarakat Nusantara. Di Aceh proses perkembangan Islam memang terjadi melalui proses penaklukan dimana seluruh elemen budaya lokal tunduk di bawah Islam. Namun hal itu tejadi pada awal kehadiran Islam di Aceh. Sementara proses beriktunya justru berjalan melalui alur integrasi dan dialog. Islam di Pasai, Malaka, Jawa Ternate dan Lombok mengkonfirmasi variasi-variasi Islam di Indonesia. Studi ini menyimpulkan bebagai pola dalam hubungan antara Islam dan budaya lokal melalui pola integrasi, inkulturasi, dan dialog.

\section{H. Islam Kultural dan Civil Islam}

Civil Islam sangat mungkin menjadi salah satu jalan agar Islam bisa ditarik dari pinggiran esklusivisme fundamentalis dan privatisasi ala pemikiran liberal sekuler ke dalam agama publik yang mengedapankan keadaban (civility) demokrasi. Dengan civil Islam berarti kita menarik agama dari upaya deprivatisasi dan sekularisasi dan sebaliknya memasukan Islam ke dalam apa disebut oleh Jose Casanova sebagai agama pulik. Islam sebagai agama publik itu merupakan gagasan yang pararlel dengan gagasan Abdurrahman Wahid tentang pribumisasi Islam yang bertujuan untuk menjadikan Islam sebagai etika sosial. Islam, demikian menurut Wahid, seharusnya tidak 
menampilkan diri dalam bentuk eksklusif, yakni tidak menampilkan warna keislamannya, tetapi mengintegrasikan kegiatannya dalam kegiatan bangsa secara menyeluruh. Islam juga harus dihindarkan agar tidak diletakkan di bawah wewenang negara melainkan menjadi kesadaran kuat dari warga masyarakat. Hal ini berarti pula meletakkan Islam sebagai kekuatan transformatif dan sebagai kekuatan kultural. Dengan lebih berorientasi kepada masyarakat berarti pula maka civil Islam memfokuskan perjuangan pada penciptaan etika sosial baru yang penuh dengan semangat solidaritas dan jiwa transformatif yang prihatin terhadap nasib orang kecil.

Kalau civil Islam merupakan gagasan bagi upaya deprivatisasi agama (Islam) pertanyaan selanjutnya adalah apa kontribusi Islam kultural bagi kehidupan publik Indonesia? Uraian di bawah ini bermaksud mengurai idealitas Islam kultural dalam mewujudkan kehidupan agama yang lebih ramah sehingga bisa diterima oleh publik Indonesia yang sangat plural. Sebelumnya perlu diuraikan terlebih dahulu tentang gagasan civil Islam. Civil Islam, memiliki penekanan pada gagasan mengenai Islam sipil demokratis. Oleh karena itu ketika kita bicara tenang civil Islam maka sesungguhnya kita bicara tentang Islam pada tataran publik, bukan pada tataran komunal, seperti keluarga, individu dan upacara-upacara ritual yang merupakan dimensi privat dalam kehidupan agama. Deprivatisasi agama (Islam) dan menjadikannya masuk dalam kehidupan publik, menurut Jose Casanova dibenarkan dengan tiga alasan sebagai berikut:

Pertama, ketika agama memasuki ruang publik untuk melindungi bukan hanya prinsip kebebasan agama yang dimilikinya, tetapi juga keseluruhan prinsip kebebasan dan hak-hak untuk manusia modern, termasuk hak paling mendasar dari masyarakat sipil yang demokratis untuk hidup dan eksis melawan negara absolut dan otoriter. Dalam konteks ini Casanova memberikan ilustrasi peran gereja Katolik dalam proses demokratisasi di Spanyol, Polandia dan Brazil sebagai contoh sangat menarik. Gereja di negara-negara itu memasuki ruang publik dengan mendorong masyarakat untuk meruntuhkan kekuasaan yang absolut dan otoiter.

Kedua, ketika agama memasuki ruang publik untuk mempertahankan dan menggugat otonomi wilayah sekuler yang kendati absah tapi bersifat absolut, termasuk klaim-klaimnya yang diatur berdasarkan prinsip diferensiasi fungsional namun mengabaikan pertimbangan-pertimbangan 
etis atau moral. Gugatan para pemimpin agama seperti para Uskup Katolik di Amerika yang mempertanyakan 'moralitas' perlombaan senjata dan kebijakan negara tentang nuklir merupakan contoh menarik dalam hal ini. Contoh lain adalah gugatan para aktivis agama yang mempertanyakan pesoalan 'keadilan' dan konsekuensi-konsekuensi yang tidak manusiawi dari sistem ekonomi kapitalis yang cenderung memutlakkan hak milik pribadi serta menklaim dirinya diatur sendiri oleh hukum-hukum pasar yang tak terbatas. Ini semua merupakan contoh gerakan agama dalam kasus ini.

Ketiga, ketika agama memasuki ruang publik untuk melindungi dunia hidup (life world) tradisional dari campur tangan yuridis maupun administratif negara, agama juga membuka isu-isu menyangkut formasi norma-noma dan kehendak ke dalam proses refleksi diri, secara kolektif dan publik etika diskursif modern. Casanova membei contoh mobilisasi publik yang dikenal dengan 'mayoritas moral' di Amerika pada tahun 1979 dan penentangan publik Katholik terhadap aborsi dengan mendukung prinsip hak untuk hidup.

Dengan demikian civil Islam merujuk pada nilai-nilai atau moralitas agama yang telah mengalami transformasi dari runag privat yang primordial dan komunal ke wilayah publik yang terbuka dan rasional. Dengan cara ini maka Civil Islam juga menggeser orientasi politik gerakan agama dari orientasi semata kepada negara menjadi berorientasi kepada dan di dalam masyarakat. Ringkasnya lokus perjuangan Islam bukan lagi pada upaya merebut negara yang menjadikannya identik secara struktural sebagaimana yang berlaku dalam sistem gereja abad pertengahan, tetapi lebih kepada ruang publik.

Karena proses deprivatisasi agama ini berlangsung dalam ruang publik, yakni dalam lokus masyarakat sipil, maka tentu agama menarik jarak antara dirinya dengan negara dan juga partai-partai politik yang tergabung dalam lokus masyarakat politik (political society). Orientasi perjuangan semacam ini jelas bukan perkara mudah. Pertama karena elit agama yang telah menikmati berbagai keuntungan dengan mengunakan agama sebagai kendaraan politik dan kekuasaan. Kedua pemisahan antara agama dan negara dalam dunia Islam merupakan masalah yang masih diperdebatkan. Presedan lama mengenai pemisahan agama dan negara sebagaiamana dalam praktek penyelenggaraan negara di Turki tampaknya akan mengalami pergeseran, terutama dengan menangnya partai AKP yang berbasiskan Islam. Dan 
peristiwa di Turki ini jelas akan sangat berpengaruh terhadap belahan dunia Islam lainnya termasuk Indonesia.

Namun demikian mengenai masyarakat sipil sebagai lokus perjuangan agama bukannya tidak memiliki preseden dalam pemikiran Islam. Memang harus diakui bahwa pemahaman masyarakat Islam hingga hari ini masih didominasi oleh konstruksi fiqh siyāsah dan siyāsah shar'iyyah yang sangat berorientasi pada negara. Selama ini ajarah fiqh siyāsah dan siyāsah shar'iyyah masih didominasi oleh kalangan Sunni Asy'ari yang kemudian dilanjutkan oleh al-Mawardi, al-Ghazali dan juga Ibn Taimiyah. Ulama-ulama ini dan masyarakat Sunni pada umumnya melihat imāmah hanya sebatas urusan negara. Oleh karena itu politik yang dipahami kalangan tradisionalisme Islam dan juga kalangan neomodernis Islam, yang keduanya sama-sama Sunni adalah politik negara, bukan di luar negara, yakni dalam masyarakat (society). Siyasah dan imamah dalam wacana politik sunni hanya berususan dengan penguasa yang dikenal dengan sultan, imam dan khalifah. Dalam wacana politik semacam ini maka urusan-urusan politik diserahkan kepada penguasa yang dalam bahasa politik sekarang disebut dengan state.

Dalam konteks inilah Islam Kultural merujuk kepada pemikiran lain yang menegaskan pendekatan politik yang rasional dan berupaya untuk memisahkan agama dan negara. Pemikir-pemikir semacam Ahmad bin Yusuf, Walad al-Dayah, Ibn Bathriq dan Ibn Rusyd merupakan pemikir Muslim yang menjadi rujukan bagi praktek politik yang tidak berorientasi pada negara, namun sebaliknya berorientasi kepada masyarakat sipil. Ibn Rusyd mislkan menyatakan bahwa "Lā siyadah fi 'd-dakhil al-madīnah al-jama'iyah illa biirādah al-musawadin wa tab'an lil-qawānin al-ulā al-fithiyah" (tidak ada kedaulatan dalam demokrasi, kecuali berada di tangan warga negara atau rakyat, dan sesuai dengan hukum-hukum dasar fitrah yang menghargai kebebasan manusia).

\section{Revitalisasi Islam Kultural: Penyegaran Gagasan dan Gerakan}

Islam kultural sebagaimana banyak diintrodusir oleh komunitas pengusungnya menawarkan penyegaran bagai tradisionalisme Islam di satu sisi dan modernisme Islam pada sisi yang lain. Pada sayap tradisional misalkan muncul apa yang disebut sebagai post tradisionalisme Islam 
sementara pada sayap modernis muncul apa yang disebut sebagai post puritanisme Islam. Sebaga upaya revitalisasi Islam kultural juga menawarkan penyegaran dalam tradisi pembacaan sumber-sumber tekstual kehidupan umat Islam dengan merujuk pada berbagai pemikir yang merupakan persambungan dari post tradisionalisme Islam.

Sebagai masyarakat agama, umat Islam disebut sebagai masyarakat dengan peradaban teks (hadarat al-naș). ${ }^{11}$ Yaitu suatu masyarakat yang struktur kehidupannya diletakkan di atas landasan teks (al-Qur'an, hadits, tafsir, kitab-kitab fiqh dan sebagainya). Dalam masyarakat semacam ini maka teks menjadi sentral dalam kehidupan. Dalam artian ini seluruh aktivitas masyarakat Islam mesti berangkat dari dan melalui serta berakhir pada teks.

Ada dua persoalan dalam masyarakat dengan perdaban teks itu. Pertama, sikap dan cara pandang masyarakat terhadap teks, kedua, cara baca (sistem nalar) yang digunakan masyarakat yang bersangkutan terhadap teks sebagai bagian dari kekayaan tradisi (turath) yang dimiliki. Dengan demikian salah satu persoalan crucial yang menentukan bagi kehidupan masyarakat Islam dewasa ini adalah bagaimana menyikapi tradisi (turath) yang telah diwarsisi dari generasi ke generasi sepanjang sejarah. Mengingat tradisi, sebagaimana dikatakan Hasan hanafi (1992: 15), merupakan khazanah kejiwaan manusia (al-makhzūn al-nafs), yang menjadi pedoman dan piranti dalam membentuk masyarakat. Implikasinya tradisi kemudian menjadi kitab suci yang harus dipedomani dalam perilaku kehidupan sehari-hari. Ada penghargaan, pembelaan bahkan "pemberhalaan" luar biasa terhadap tradisi melalui suatu proses sakralisasi pemikiran keagamaan (taqdīs al-afkār aldiny). Sakralisasi ini berlaku bukan hanya bagi teks primer (al-Qur'an) dan Teks sekunder (al-Hadits), tetapi juga berlaku bagi teks-teks tersier (tafsir, fiqh dan sebagainya). Dalam hal ini tradisi kemudian berubah menjadi tradisionalisme. Kungkungan tradisionalisme kemudian tampak dalam cara baca tardisional. Sebagian umat Islam memang ingin mencoba beranjak dari tradisonalisme dengan semangat merujuk secara langsung kepada teks primer dan sekunder (rujū' ila 'l-Qur'ān wa 'l-Sunnah) namun sakralisasi telah

11 Menurut Nasr Hamid Abu Zaid, kalau boleh menyimpulkan peradaban dalam satu dimensi saja, maka dapat dikatakan bahwa peradaban Mesir Kuno adalah peradaban "pascakematian", peradaban Yunani adalah peradaban "akal", sementara peradaban Arab Islam adalah peradaban "teks". Selengkapnya lihat Nasr Hamid Abu Zaid, Tekstualitas Al-Qur'an, (Yogyakarta: LKiS, 2002), h. 1-2. 
menjebak mereka ke dalam kungkungan skripturalisme yang cenderung fundamentalistik dan radikal.

Inilah tampaknya yang menjadi problem crucial lain dalam dunia Islam. Oleh karena itu Metode tradisional dalam menelaah tradisi (qirä'ah turathiyyah li al-turath) tampaknya sudah harus dilampaui oleh umat Islam dengan mengambil cara baca kontemporer (al-qirā'ah al-muașirah). Dengan cara baca kontemporer inilah umat Islam bisa lebih produktif dalam mengembangkan wacana keislaman dan responsif terhadap tantangan dan perubahan sosial dan kultural.

\section{J. Kesimpulan}

Umat Islam Indonesia pasca reformasi memainkan apa yang saya sebut sebagai total politik. Fenomena total politik dalam strategi perjuangan politik politik umat Islam itu akan berpengaruh terhadap hubungan Islam, negara dan civil society. Dari sudut kontestasi gerakan kini telah terjadi pergeseran dan persilangan, yang mengakibatkan banyak cabang dan sayap dalam gerakan-Islam Indonesia kontemporer yang ditandai dengan munculnya organisasi dan gerakan Islam baru.

Mencairnya batas-batas demarkasi antara Islam tradisional dan Islam modermsis sayangnya tidak dibarengi dengan sinergi yang lebih bersifat kultural dari dua organisasi terbesar itu. Sebaliknya ada kecenederungan yang terjadi adalah dominasi pertarungan politik yang banyak menguras energi sosial dan kultural. Memang terdapat sejumlah perkembangan baru dalam dinamika pemikiran, dengan munculnya kelompok minoritas yang menginrodusir gagasan baru yang relevan dengan gerakan Islam kultural seperti multikulturalisme, da'wah kultural, gerakan antri korupsi serta apresaisi terhadap seni dan kebudayaan lokal. Namun demikian kuatnya orientasi politik gerakan-gerakan Islam Indonesia merpakan kenyataan yang tak terbantahkan. Kurangnya apresasi terhadap kenyataan budaya dan orientasi yang sangat kuat terhadap negara itu sesungguhnya merupakan akibat panjang dari cengkeraman ortdoksi dalam gerakan Islam.

Memang harus diakui bahwa pemahaman masyarakat Islam hingga hari ini masih didominasi oleh konstruksi fiqh siyasah dan siyasah syar'iyah yang sangat berorientasi pada negara. Selama ini ajarah fiqh siyāsah dan siyāsah shariyyah masih didominasi oleh kalangan Sunni Asy'ari yang kemudian 
dilanjutkan oleh al-Mawardi, al-Ghazali dan juga Ibn Taimiyah. Ulama-ulama ini dan masyarakat sunni pada umumnya melihat imāmah hanya sebatas urusan negara. Oleh karena itu politik yang dipahami kalangan tradisionalisme Islam dan juga kalangan neomodernis Islam, yang keduanya sama-sama sunni adalah politik negara, bukan di luar negara, yakni dalam masyarakat (society).

Teks-teks fiqh semacam inilah yang kemudian berkelindan dengan cara pembacaan umat Islam, yaitu cara pembacaan teks yang ideologis dan tendensius. Pembacaan teks yang ideologis dan tendensius berarti membaca teks yang didasarkan atas kepentingan-kepentingan politik kekuasan yang tersembumyi dibelakangnya. Cara baca ideologis tendensius inilah yang kini tengah marak dalam wacana dan gerakan Islam di Indonesia. Dari sinilah maka tawaran hermeneutika menemukan relevansinya. Dengan menawarkan hermeneutika sebagai metode penafsian para pengusung gerakan kultural sedang menawarkan cara baru pembacaan tradisi dan berusaha untuk menawarkan penyegaran terhadap tradisi.

Di sisi lain penguatan Islam kultural juga mengharuskan pergeserean atau paling tiak perhatian berimbang terhadap lokus pengembangan civil Islam. Civil Islam merujuk pada nilai-nilai atau moralitas agama yang telah mengalami transformasi dari runag privat yang primordial dan komunal ke wilayah publik yang terbuka dan rasional. Dengan cara ini maka Civil Islam juga menggeser orientasi politik gerakan agama dari orientasi semata kepada negara menjadi berorientasi kepada dan di dalam masyarakat. Ringkasnya lokus perjuangan Islam bukan lagi pada upaya merebut negara yang menjadikannya identik secara struktural sebagaimana yang berlaku dalam sistem gereja abad pertengahan, tetapi lebih kepada ruang publik.

Karena proses deprivatisasi agama ini berlangsung dalam ruang publik, yakni dalam lokus masyarakat sipil, maka tentu agama menarik jarak antara dirinya dengan negara dan juga partai-partai politik yang tergabung dalam lokus masyarakat politik (political society). Orientasi perjuangan semacam ini jelas bukan perkara mudah. Pertama karena elit agama yang telah menikmati berbagai keuntungan dengan mengunakan agama sebagai kendaraan politik dan kekuasaan. Kedua pemisahan antara agama dan negara dalam dunia Islam merupakan masalah yang masih diperdebatkan.[w] 


\section{BIBLIOGRAFI}

Adas, Michael, Prophets of Rebellion: Millenarian Protest Movements against the European Colonial Order, University of North Carolina Press, 1979, terj. Ratu Adil: Tokoh dan Gerakan Milenarian Menentang Kolonialisme Eropa, Jakarta: Rajawali, 1988.

Althusser, Louis, Lenin, His Philosophies and The Order Essay, London: New Left Book, 1971.

Bowen, John R., "The Myth of Global Ethnic Conflict" dalam Journal of Democracy 7: 4, October 1999.

Coleman, John A., “Civil Religion” dalam Meaning and Modernity: Religion, Polity and Self, California: University of California Press, 2003.

Effendy, Bachtiar, Islam dan Negara, Jakarta: Paramadina, 1999.

Geertz, Clifford, The Religion of Java, Glencoe, III: The Free Press, 1960 Islam Observed, Chicago, University of Chicago Press, 1968.

Gellner, Ernest, Muslim Society, Cambridge: Cambridge University Press, 1981.

Hammond, Philip E., "Pluralisme dan Hukum dalam Pembentukan Agama Sipil Amerika" dalam Varieties of Civil Religion, terj. Imam Khoiri dkk. Yogyakarta: IRCISoD, tt.

Hardjono, "Eksistensi Khonghucu di Indonesia Ditinjau dari Perspektif Yuridis" dalam Hak Asasi Beragama dan Perkawinan Khonghucu Perspektif Sosial, Legal dan Teologi, Jakarta: PT. Gramedia Pustaka Utama, 1998.

Hefner, Robert W., Civil Islam: Muslim and Democratization in Indonesia, Princeton University Press, 2000.

Hidayat, Komaruddin, dan Ahmad Gaus AF (ed.), Islam Negara dan Civil society, Jakarta: Paramadina, 2005.

Holt, Claire, (ed), Culture and Politics in Indonesia. Ithaca: Cornell University Press, 1972.

Walisongo, Volume 21, Nomor 2, November 2013 
J.J Rousseau, The Social Contract, London: Penguin Books, 1968.

Jackson, Karl. D, Tradisional Authority, Islam and Rebellion A Study Of Political Behevior, New York: Penguin, 1979.

Jurnal Dialog, Edisi II Tahun 2004.

Kurtz, Lester, God in The Global Village, California: Pine Forge Press, 1995.

Maliki, Zainuddin, Agama Rakyat Agama Penguasa, Yogyakarta: Galang Press, 2000.

Muhammad, Ashari, Aurad Muhammadiyah, Pegangan Darul Arqam. Kuala Lumpur: Penerangan Al Arqam, 1986.

Mulyoudarmo, Suwoto, "Pertimbangan Putusan Hakim dalam Kasus Penolakan Pencatatan Perkawinan", dalam Hak Asasi Beragama dan Perkawinan Khonghucu Perspektif Sosial, Legal dan Teologi, dan Perkawinan Khonghucu Perspektif Sosial, Legal dan Teologi, Jakarta: PT. Gramedia Pustaka Utama, 1998.

Niebuhr, H. Richard, The Social Sources of Denominationalism, New York: Holt, 1929.

Patria, Nezar, dan Andi Arief, Antonio Gramsci: Negara dan Hegemoni, Yogyakarta: Pustaka Pelajar, 1999.

Robertson, Roland, (ed.), Agama: dalam Analisa dan Interpretasi Sosiologis. Jakarta: Rajawali, 1988.

Saidi, Anas (ed), Menekuk Agama, Membangun Tahta, Jakarta: Desantara, 2004.

Scumann, Olaf, "Bellah dan Wacana 'Civil Religion' di Indonesia” Dalam Robert N. Bellah, Beyond Belief: Esai-Esai tentang Agama di Dunia Modern, terj. Rudi Harisah Alam, Paramadina Jakarta, 2000.

Shihab, Alwi, Islam Sufistik: "Islam Pertama" dan Pengaruhnya Hingga Kini di Indonesia, Bandung: Mizan, 2001.

Sidiqui, Kalim, Pursuit of the Power of Islam, The Open Press, 1992.

Smith, Donald E., Religion and Political Development, Boston: Litlte Brown and Company, 1970.

Stange, Paul, The Sumarah Movement in Javanese Mysticism, Ph.D. thesis, University of Wisconsin, Madison, 1980. 
Taswirul Afkar, Edisi No 4 Tahun 1999.

Tibi, Basam, Islam and the Cultural Accomodation of Social Change, Boluder, Colo: Westview, 1990.

Troeltsch, Ernest, The Social Teachings of the Christian Churches, London, 1931.

Voll, John Obert, Islam Continuity and Change in the Modern World, The United States of American Westview Press, 1982.

Yinger, J. Milton, Religion, Society and the Individual. New York: MacMillan Co., 1957. 
Walisongo, Volume 21, Nomor 2, November 2013 